\title{
SF-1 mediates reproductive toxicity induced by Cerium oxide nanoparticles in male mice
}

\author{
Fenju Qin ${ }^{1,3^{*}}$ (D) Tao Shen ${ }^{1}$, Jinlin Li ${ }^{1}$, Junchao Qian ${ }^{1}$, Jie Zhang ${ }^{2}$, Guangming Zhou ${ }^{3}$ and Jian Tong ${ }^{2 *}$
}

\begin{abstract}
Background: Cerium oxide nanoparticles $\left(\mathrm{CeO}_{2} \mathrm{NPs}\right)$ have potential application for use in biomedical and in various consumer products. However, it is largely unclear whether $\mathrm{CeO}_{2} \mathrm{NPs}$ have effects on male reproductive function.

Methods: In this study, male mice were examined for toxicity, if any, following chronic oral administration of $\mathrm{CeO}_{2}$ NPs for 32 days. In each animal, epididymides were examined for sperm motility and DNA integrity. Bloods were tested for testosterone levels. Testicular tissues were collected to determine the element Ce content, the daily sperm production (DSP), marker enzymes such as ACP, G6PD, $\gamma-\mathrm{GT}$ and SDH, mRNA expression levels of steroidogenesis

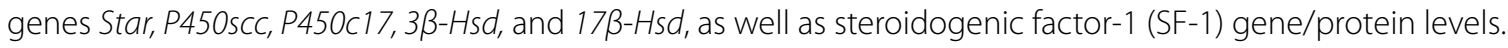

Results: The results showed that $\mathrm{CeO}_{2} \mathrm{NPs}(20 \mathrm{mg} / \mathrm{kg}$ and $40 \mathrm{mg} / \mathrm{kg}$ ) increased the element Ce content in testis, the testis histopathological patterns and sperm DNA damage whereas decreased the testis weight, DSP and sperm motility. There were also remarkable reduction in testosterone levels and marker enzymes activities, down-regulated mRNA expression levels of several steroidogenesis genes such as Star, P450scc, P450c17, 33-Hsd, and 17 $3-H s d$, as well as altered gene and protein expressions of SF-1.
\end{abstract}

Conclusion: These results reveal the male reproductive toxicity of chronic exposure of $\mathrm{CeO}_{2} \mathrm{NPs}$ in mice, hinting that the utilization of $\mathrm{CeO}_{2} \mathrm{NPs}$ need to be carefully evaluated about their potential reproductive toxicity on the human health.

Keywords: $\mathrm{CeO}_{2} \mathrm{NPs}$, Reproductive toxicity, Testosterone, Steroidogenesis genes, SF-1

\section{Background}

There are more than 1814 different nanomaterials that are currently used in consumer products because of their unique properties such as magnetism, thermotics, and optics $[1,2]$. The potential health risk of engineered nanomaterials has been a great concern of the general public, but only $3 \%$ of the investigation on nanoparticles (NPs) is devoted to their biological effects [3, 4]. Lack of adequate knowledge of the adverse effects of nanomaterials, together with intentional therapeutic use and unintentional environmental contamination, has exposed the public from unperceived health risks. The extremely

\footnotetext{
*Correspondence: qinfenju@usts.edu.cn; tongjian@suda.edu.cn

1 School of Chemistry, Biology and Material Engineering, Suzhou

University of Science and Technology, Suzhou 215009, China

${ }^{2}$ School of Public Health, Medical College of Soochow University,

Suzhou 215123, China

Full list of author information is available at the end of the article
}

small size of nanoparticles enable them cross biological membranes and enter into the cell $[5,6]$. Getting into the circulatory system by inhalation, ingestion, or penetration through the skin, NPs can be distributed to other organs and tissues in the body to induce adverse effects such as oxidative stress, activation of inflammatory cytokines, gene mutations and even cell death $[7,8]$.

The existing knowledge on potential adverse effects of NPs on reproductive system is not complete. There were some reports that the metal NPs could be found in animal testicles and ovaries after in vivo exposure $[9,10]$. Among the various nanomaterial products, cerium oxide $\left(\mathrm{CeO}_{2}\right)$, a lanthanide element oxide, is widely used in industry processing such as benzene degradation, manufacture of solar/fuel cells, UV absorbents, oxygen sensors, oxygen pumps, polishers for chemical mechanical planarization, metallurgical, ceramic and smart glass, etc. [11-13]. As a result, the numbers of workers exposed to $\mathrm{CeO}_{2}$ 
nanoparticles increase rapidly. There are studies which have investigated the bio-distribution, bio-accumulation of $\mathrm{CeO}_{2} \mathrm{NPs}$ in vivo and the toxicity in lung, liver and blood, even DNA damage [14-16]. However, the impact of $\mathrm{CeO}_{2} \mathrm{NPs}$ on reproductive function, particularly on male reproductive system, remains poorly understood. The experimental results from available reports so far in scientific literature were largely controversial. Some studies showed a remarkable increase in DNA damage in mouse sperm induced by $\mathrm{CeO}_{2}$ NPs even at concentrations as low as $0.01 \mathrm{mg} / \mathrm{L}$ [17]. In vitro exposure of human spermatozoa to $\mathrm{CeO}_{2}$ was also reported to induce cellular damage due to the accumulation of nanoparticles on the plasma membranes [18]. In contrast, short-term in vitro exposure of $\mathrm{CeO}_{2} \mathrm{NPs}$ did not induce changes in ram sperm function and morphology [19]. $\mathrm{CeO}_{2} \mathrm{NP}$ was also reported to be found in the testicles and epididymis in rats after inhalation, but the reproductive outcomes associated with $\mathrm{CeO}_{2} \mathrm{NP}$ accumulation in testis were not assessed [20]. Overall, the available information on the male reproductive toxicity of $\mathrm{CeO}_{2} \mathrm{NP}$ is very limited and incomplete [21].

In the present study, the possible impact of chronic exposure to $\mathrm{CeO}_{2} \mathrm{NP}$ on the element $\mathrm{Ce}$ content in testis, sperm parameters, integrity of the DNA, histopathology, testis marker enzymes, testosterone levels, and expression of genes involved in steroidogenesis were evaluated, in order to explore potential health effects of chronic administration of $\mathrm{CeO}_{2} \mathrm{NP}$ on the male reproductive function.

\section{Materials and methods}

\section{Animal handling}

Adult male 6 week-old C57BL/6J mice weighing $22 \pm 2 \mathrm{~g}$ were obtained from the laboratory animal center of Soochow University. They were maintained in strict accordance with the Institutional Animal Care and Use Committee guidelines of the University. The animals were housed in a facility maintaining $25+2{ }^{\circ} \mathrm{C}$ temperature, $50+5 \%$ relative humidity and $12 \mathrm{~h}$ light/dark cycles. They were fed with commercial diet and provided water ad libitum. After 7 days of quarantine, the animals were randomly divided into one control group and three experimental groups, each with 12 mice. The 3 experimental groups were given oral administration of $\mathrm{CeO}_{2}$ NPs (Sigma-Aldrich, Shanghai, China) at doses of 10, 20 or $40 \mathrm{mg} / \mathrm{kg}$ body weight, respectively, for 32 consecutive days at 9:00 AM every day. Nanoparticles were suspended in $0.50 \%$ solvent (carboxymethylcellulose sodium salt, Sigma-Aldrich, China) by ultrasonication and vortexed before every treatment. The control mice were given the same volume of $0.50 \%$ solvent at the same time each day. In the thirty-third day, all mice were sacrificed by cervical dislocation. From each animal, blood was collected by periorbital puncture into heparinized tubes and plasma was separated for determination of testosterone using ELISA kit. The sperm was collected from epididymis to examine the motility and DNA integrity. The right testis randomized from 6 mice in each group was excised, fixed and tissue sections were used for histological evaluation, the left testis was kept frozen at $-80^{\circ} \mathrm{C}$ for ICP-MS analysis. For the testis from the other 6 mice in each group, the right was immediately used to test testicular enzymes activities and sperm head count, the left was kept frozen until used for real-time PCR or Western blot test.

\section{Nanoparticles}

The cerium oxide nanoparticles (Product Number: 544841, APS: $<25 \mathrm{~nm}$ and purity $>99 \%$ trace metal basis) were obtained from Sigma-Aldrich (Shanghai, China). Their characteristics were tested by X-ray powder diffractometry (XRD8 Advance X-ray diffracto

-meter, Bruker AXS Endeavor, Billerica, USA), SEM (Quanta FEG 250, Hillsboro, USA) and transmission electron microscope (TEM, JEOL 2100, Tokyo, Japan) and presented in Fig. 1a-c. The X-ray diffraction of the precipitated material showed cubic crystals. The intense peaks from the XRD test corresponded to the diffraction peak of $\mathrm{CeO}_{2}$. The average size of $\mathrm{CeO}_{2} \mathrm{NP}$ evaluated by TEM was $27.62 \pm 3.01 \mathrm{~nm}$.

\section{ICP-MS analysis}

The frozen testis was thawed, weighed and soaked in $10 \mathrm{ml}$ concentrated nitric acid overnight. Then the sample was digested in graphite digestion furnace at $300{ }^{\circ} \mathrm{C}$ until transparent. Digestion liquid was heated and vaporized to $1.5 \mathrm{ml}$. After cooling, the samples were diluted with Milli-Q water to $10 \mathrm{ml}$. The Cerium concentrations were measured using ELEMENT 2 ICP-MS (Thermo Fisher, United States) [22].

\section{Histopathology}

Histological sections of the testicular tissue $(5 \mu \mathrm{m})$ were prepared and stained with hematoxylin and eosin [23]. For each animal, 3 sections at random were examined for microscopic architectures and photographed using a fluorescence microscope (Zeiss, Germany). The extent of damage was evaluated by the percentage of degenerated tubules [24].

\section{Measurement of testosterone and marker enzymes}

For each animal, the concentration of testosterone in plasma was measured by ELISA kit (Shanghai Yili, China) according to the protocols from the manufacturer. The sensitivity of the assay ranged from 8 to $240 \mathrm{nmol} / \mathrm{l}$. The assay in each sample was repeated three times. 


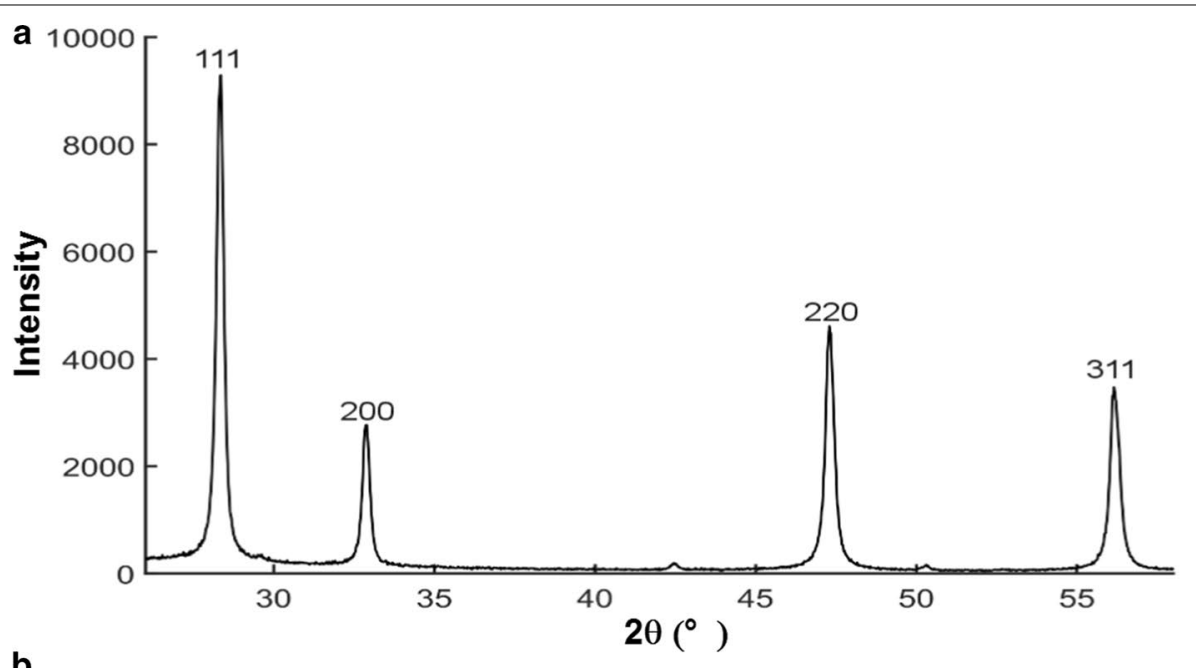

b

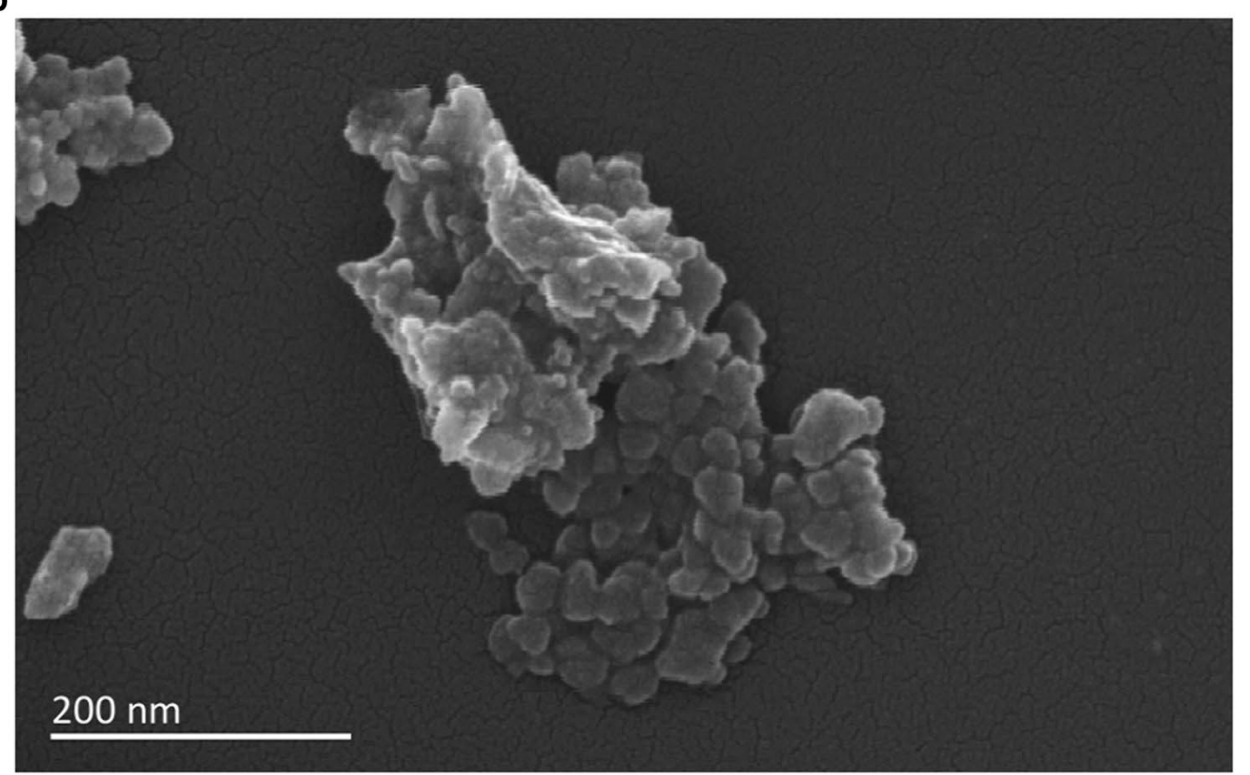

C

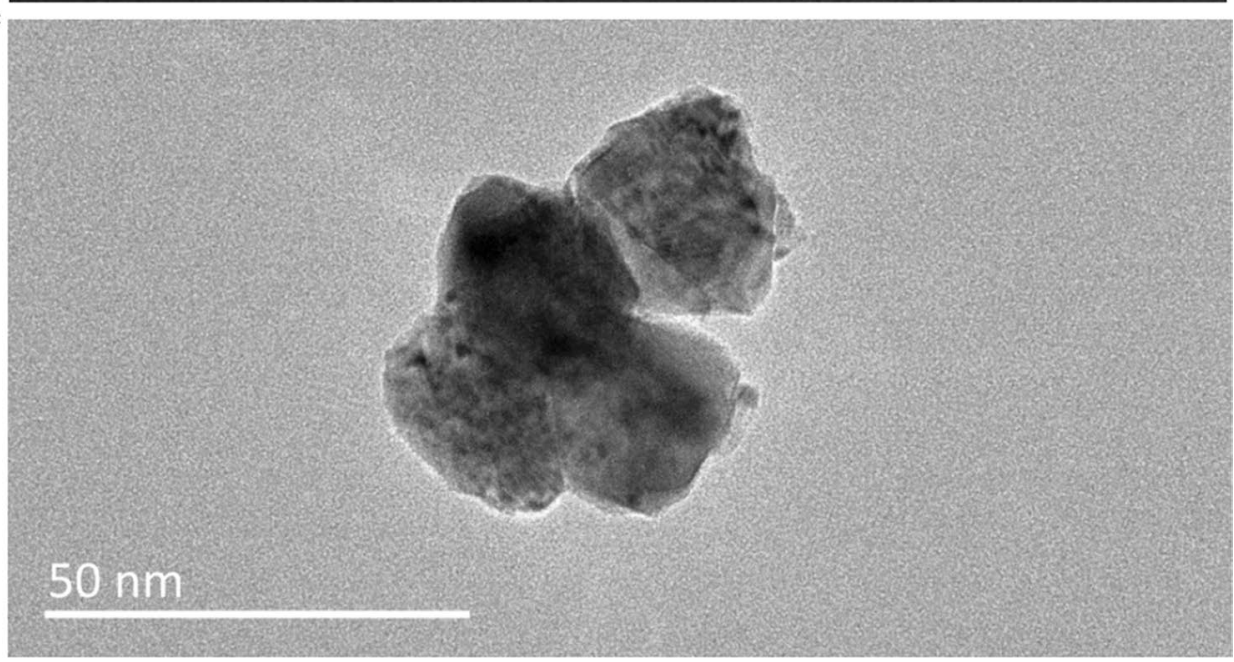

Fig. 1 Characterization of test material $\mathrm{CeO}_{2} \mathrm{NPs}$. a The results of XRD test; $\mathbf{b}$ scanning electron micrographs of $\mathrm{CeO}_{2}$; $\mathbf{c}$ transmission electron micrographs of $\mathrm{CeO}_{2}$ 
The testis from each mouse was homogenized in $0.9 \%$ normal saline containing $0.05 \%$ Triton X-100 (SigmaAldrich, China). After centrifugation, the supernatant was used to measure the levels of four testis marker enzymes, viz., acid phosphatase (ACP), glucose-6-phosphate dehydrogenase (G6PD), $\gamma$-glutamyl-transpeptidase $(\gamma-\mathrm{GT})$ and succinate dehydrogenase $(\mathrm{SDH})$ using commercially available kits (Suzhou Comin Biotechnology Co., Ltd, China).

\section{Daily sperm production (DSP)}

The number of sperm produced per gram testicular tissue every day was detected and calculated as described by Joyce et al. [25]. Briefly, testes were weighed, decapsulated, and homogenized in ice-cold physiological saline solution containing $0.01 \%$ Triton X-100. The homogenate was defoamed by $1 \mathrm{~min}$ settling and was gently mixed and stored on ice. An aliquot of the homogenate was used to evaluate the number of spermatozoa with a hemocytometer for 14-16 spermatids (stages II-VIII) surviving after this homogenization. The total spermatids value per testis was divided by testis weight (g) and the time (days) during spermatogenesis to obtain the daily sperm production (DSP). It is worth noting that the time (days) during spermatogenesis is 4.84 days for mice [26]. Each sample was examined three times and averaged.

\section{Sperm motility and DNA integrity}

For each mouse, the left epididymis was used to obtain a free sperm suspension by mincing in warm Hank's solution $\left(\mathrm{Ca}^{2+}\right.$ and $\mathrm{Mg}^{2+}$ free). The motility of sperm was classified according to instructions in WHO (1992). Each sample was examined three times.

Sperm DNA integrity was determined by SCSA using acridine orange (AO) staining kit (Hezhong biotechnology co., Ltd, China) to distinguish the sperm metachrome shift according to change in fluorescence from green to orange-red (undenatured DNA to denatured DNA) as described by Duale et al. [27]. A small aliquot of sperm suspension from the right epididymis was washed and centrifuged. The cell pellet was diluted, resuspended with dilution solution and $15 \mu \mathrm{l}$ sperm suspension was added on a microscope slide, $2 \mathrm{ml}$ fixative was added after drying, and then, fixed for $5 \mathrm{~min}$ and stained with AO staining solution for $15 \mathrm{~min}$ at $37{ }^{\circ} \mathrm{C}$ protected from light. Then staining solution was washed and the slides were covered with glycerol medium. The smear with AO staining was examined and photographed using a fluorescence microscope (Zeiss, Germany). The green fluorescence color reflects the sperm with normal double-stranded DNA while the red fluorescence color denoted denatured sperm DNA. In each sample, 200 sperm were examined to record the percentage with red fluorescence sperms.

\section{Real-time PCR}

Total RNA extraction of each testis was conducted using High Pure RNA kit from Roche, Switzerland. Then NanoDrop $^{\text {TM }} 2000 C$ was used to detect the RNA concentration at $260 \mathrm{~nm}$. The reverse transcription and real-time PCR was carried out as described earlier [28]. The sequences of the primers $(S f-1, S t A R, P 450 s c c, P 450 c 17$, $3 \beta-H S D, 17 \beta-H S D)$ used are shown in the following. The $2^{-\Delta \Delta \mathrm{Ct}}$ method was used to calculate the fold-change of mRNA in testis and $\beta$-actin was taken for internal control. Every sample was measured in three times.

Sf-1-F (5'-TTCTGAGAGCCCGCTAGCCACT-3'), Sf-1-R (5'-CGTCCGCTGAACGGAAGGAGAA-3'), StAR-F (5'-AAAGCCAGCAGGAGAACGGGGA-3'), StAR-R (5'-GCCTCCATGCGGTCCACAAGTT-3'), P450scc-F: (5'-CTGCCTGGGATGTGATTTTCA-3') P450scc-R: (5'-GTAATGTTGGCCTGGATGTTCT-3') $3 \beta$-HSD-F (5'-GCGGCTGCTGCACAGGAATA-3'), 3 $\beta$-HSD-R (5'-GACGCATGCCTGCTTCGTGA-3'), P450c17-F (5'-GATCGGTTTATGCCTGAGCG-3'), P450c17-R (5'-TCCGAAGGGCAAATAACTGG-3'), $17 \beta$-HSD-F (5'-GATGTGGCTGTCAACTGTGC-3'), 17 $\beta$-HSD-R (5'-TTGATAACCCGCTGGAAGTC-3'), $\beta$-actin-F (5'-TGGAATCCTGTGGCATCCATGAAA C-3'),

$\beta$-actin-R (5'-TAAAACGCAGCTCAGTAACAGTCC $\left.\mathrm{G}-3^{\prime}\right)$.

\section{Western blot}

For total protein extraction from the testis, Protein Extraction Kit was used (Merck Millipore, Massachusetts, USA). Protein quantification was carried by the BCA Protein Assay Kit (Merck KGaA, Darmstadt, Germany). The image of SF-1 western blots was got (Additional file 1: Fig. S1) and the operating steps were performed as described earlier [28]. The following primary and secondary antibodies were used: primary rabbit monoclonal anti-actin antibody (1:1000) (Merck Millipore, Darmstadt, Germany, Catalog\# 1501), rabbit polyclonal SF-1 antibody (1:200) (Santa Cruz Biotech, Santa Cruz, USA, Catalog\# sc-28740), secondary antibody goat anti-rabbit IgG 1:10000 (Thermo Scientific, Rockford, USA).

\section{Statistical analysis}

The data are presented as mean \pm standard error in Figures. All data were analyzed by One-way analysis of variance (ANOVA) and the F-test from SPSS 22.0. Difference between groups was considered statistically significant at $p<0.05$. 


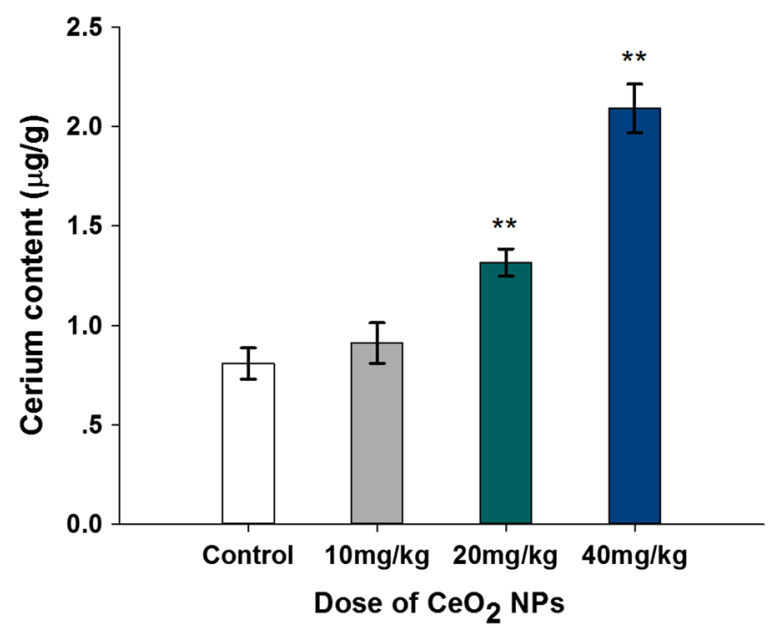

Fig. 2 Increased levels of testis element Ce content in mice following the addition of various doses of $\mathrm{CeO}_{2} \mathrm{NPs}$ for 32 days. Values are mean $\pm S D, n=6$. Significance of difference: $\mathrm{CeO}_{2} \mathrm{NPs}$ group compared with control, ${ }^{* *} p<0.01$

\section{Results}

Content of element $\mathrm{Ce}$ in testis after the exposure of $\mathrm{CeO}_{2}$ NPs

Figure 2 shows an increase of element Ce content in testis after administration of $\mathrm{CeO}_{2} \mathrm{NPs}$. There were the most significant differences between 20 or $40 \mathrm{mg} / \mathrm{kg}$ doses groups $(1.316$ or $2.092 \mu \mathrm{g} / \mathrm{g})$ and in the control group $(0.807 \mu \mathrm{g} / \mathrm{g})(p<0.01)$. The increase of element Ce content in $10 \mathrm{mg} / \mathrm{kg}$ dose animal testis was no statistically significant differences $(p>0.05)$.

\section{Testis weight and Testis-somatic index}

As shown in Fig. 3a, b, all of testis weight and testissomatic index had a decrease following $\mathrm{CeO}_{2} \mathrm{NPs}$ administration. Compared to the control group, the significant difference of testis weight appeared in $40 \mathrm{mg} / \mathrm{kg}$ doses groups by $10.54 \%(p<0.05)$, Testis-somatic index reduced in $40 \mathrm{mg} / \mathrm{kg}$ doses groups from $0.64 \%$ to $0.57 \%(p<0.05)$.

\section{DSP and sperm motility}

Oral exposure of mice to $\mathrm{CeO}_{2}$ NPs induced significant effect on the testicular DSP and the epididymis sperm motility compared with that of the control group (Fig. 4 $a$ and $b$ ). The reductions in DSPs were $26.47 \%$ and $37.71 \%$ at doses $20 \mathrm{mg} / \mathrm{kg}$ and $40 \mathrm{mg} / \mathrm{kg}$, respectively $(p<0.05$ or $p<0.01)$. A downward trend in sperm motility, $12.10 \%$ and $32.84 \%$ was also observed in mice given 20 and $40 \mathrm{mg} / \mathrm{kg}$ doses, respectively $(p<0.05$ or $p<0.01)$. However, these alterations in sperm motility and DSP were not significant in mice given $10 \mathrm{mg} / \mathrm{kg} \mathrm{CeO}{ }_{2}(p>0.05)$.

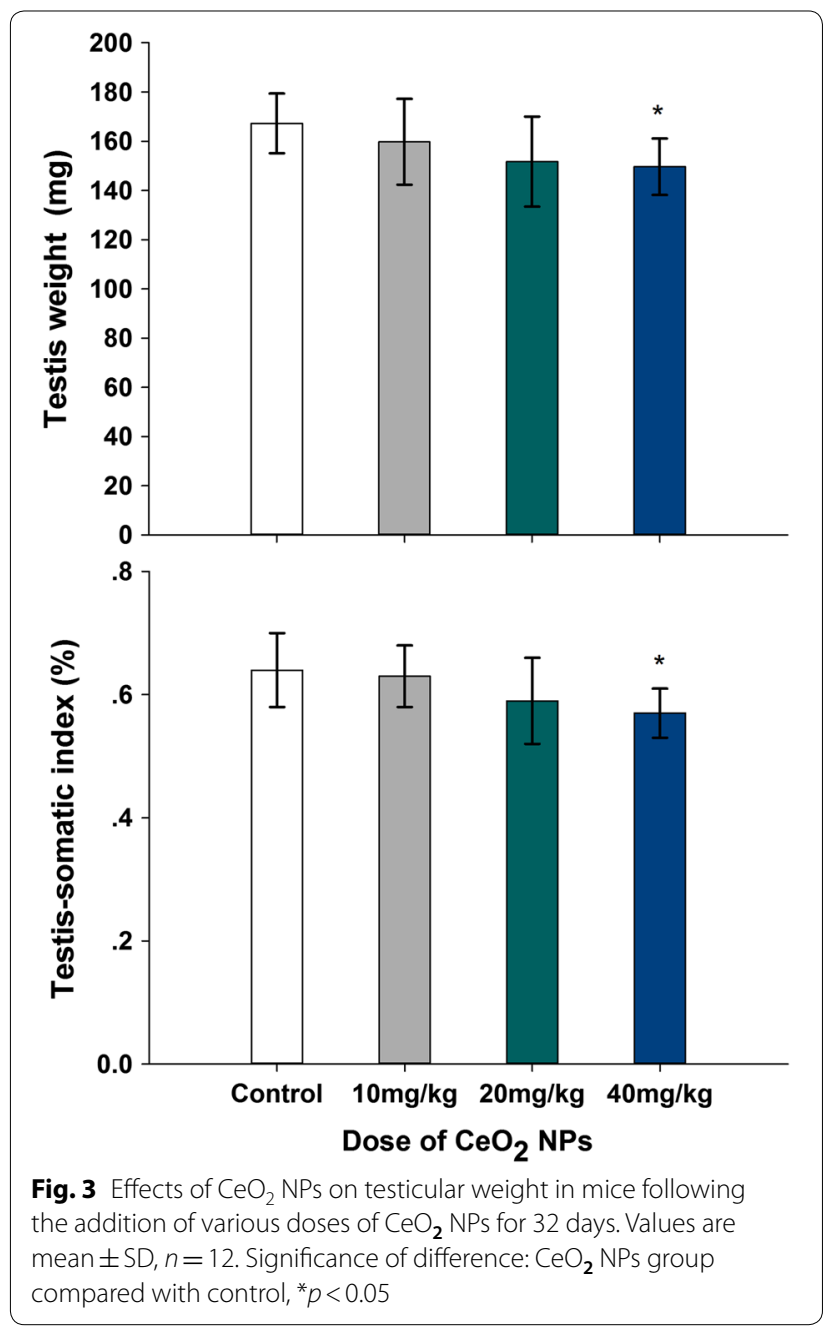

\section{Sperm DNA integrity}

The AO staining analysis revealed oral exposure $\mathrm{CeO}_{2}$ NPs in mice resulted in a concentration-dependent decrease in the epididymal sperm DNA integrity. The native DNA (green fluorescence) and denatured DNA (red fluorescence) in sperm head are showed in Fig. 5. Red fluorescence sperm ratio which represents denatured sperm DNA in 20 and $40 \mathrm{mg} / \mathrm{kg} \mathrm{CeO}_{2} \mathrm{NPs}_{\text {groups }}$ were increased significantly compared to the control from $6.93 \%$ to $12.62 \%$ or $18.29 \%(p<0.01)$. Hence, it was considered that the sperm DNA was highly susceptible to $\mathrm{CeO}_{2}$ NPs exposure.

\section{Testicular histology}

At the end of the $\mathrm{CeO}_{2}$ NPs exposure, there were degenerative changes in testis tissue (atrophy of seminiferous tubules or necrosis, the seminiferous epithelium cellular adhesion loosening or desquamation, spermatozoa loss and interstitial tissue apoptosis) in mice given 20 and $40 \mathrm{mg} / \mathrm{kg} \mathrm{CeO}{ }_{2}$ NPs compared to the control group, 

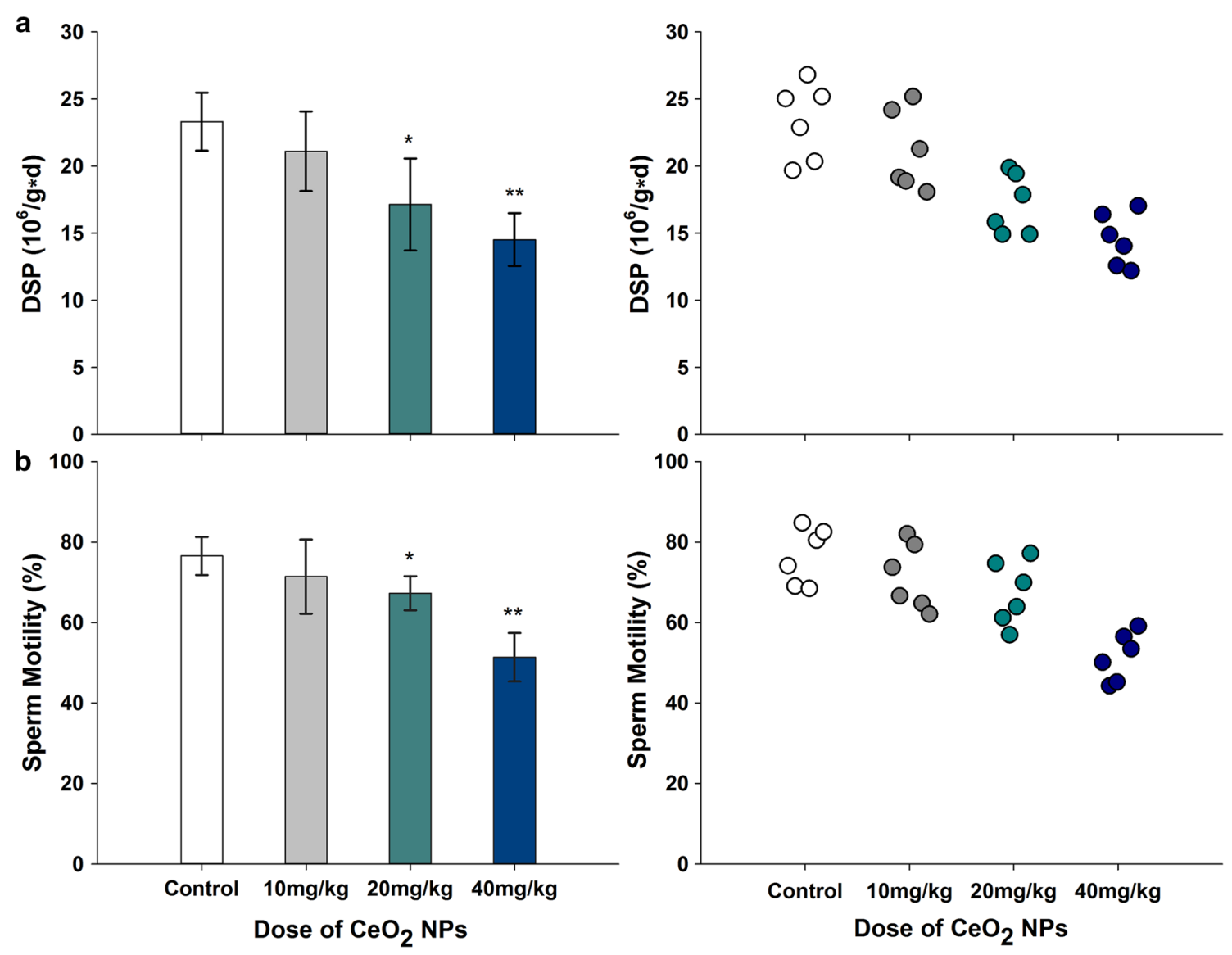

Fig. 4 Reduced levels of DSP (a) and sperm motility (b) following the addition of various doses of $\mathrm{CeO}_{2} \mathrm{NPs}$ in mice for 32 days. $n=6$. Significance of difference: $\mathrm{CeO}_{2} \mathrm{NPs}$ group compared with control, ${ }^{*} p<0.05,{ }^{* *} p<0.01$

(Fig. 6). From the histological studies, a distinct decline was presented in the several dominant cell types such as the Leydig cells, Sertoli cells, spermatogonia, primary spermatocytes and spermatids. From the tubular crosssections, the ratio of seminiferous tubule damage in the $\mathrm{CeO}_{2}$ NPs 20 and $40 \mathrm{mg} / \mathrm{kg}$ groups were significantly increased compared to control group $(p<0.01)$.

\section{Testicular enzyme assay}

The activities of testicular marker enzymes which are known to be associated with testicular function were changed after $\mathrm{CeO}_{2}$ NPs exposure. The activities of G6PD, $\gamma$-GT, and SDH in mice given $20 \mathrm{mg} / \mathrm{kg} \mathrm{CeO} \mathrm{NPs}_{2}$ were decreased significantly, $28.82 \%, 20.88 \%$, and $23.92 \%$, respectively, compared to the control group $(p<0.05)$. In the $40 \mathrm{mg} / \mathrm{kg} \mathrm{CeO} \mathrm{CPs}_{2}$ treated animals, the results indicated significant decrease in four testicular marker enzymes activities (ACP, G6PD, $\gamma-\mathrm{GT}$, and SDH) by $29.81 \%, 64.09 \%, 49.75 \%$, and $36.49 \%(p<0.01)$, respectively. The activity of G6PD was significantly reduced in the four testicular marker enzymes (Fig. 7)

\section{Plasma testosterone level ( $\mathrm{nmol} / \mathrm{L}$ )}

The administration of $\mathrm{CeO}_{2}$ NPs significantly decreased plasma testosterone concentration (Fig. 8). $\mathrm{CeO}_{2} \mathrm{NPs}$ exposure in $20 \mathrm{mg} / \mathrm{kg}$ and $40 \mathrm{mg} / \mathrm{kg}$ groups decreased the testosterone levels by $14.46 \%$ and $33.17 \%$, respectively, relative to the control mice $(p<0.05$ or $p<0.01)$.

\section{Testosterone genes expressions}

The real-time PCR results of five testosterone gene expressions (StAR, P450scc, 3 $\beta$-HSD, P450c17, 17 $\beta$ $H S D)$ are presented in Fig. $9 \mathrm{a}-\mathrm{e}$, respectively. Compared with expression levels of the five genes in control animals' testis, these data indicated that the $\mathrm{CeO}_{2} \mathrm{NPs}$ exposure induced a significant and dose-dependent decrease in 20 and $40 \mathrm{mg} / \mathrm{kg}$ dose animals $(p<0.05$ or $p<0.01)$ except 17 $\beta$-HSD $(p>0.05)$.

\section{SF-1 expressions}

The real-time PCR and Western Blot results of $S f-1$ are presented in Fig. 10a, b, respectively. Compared with 


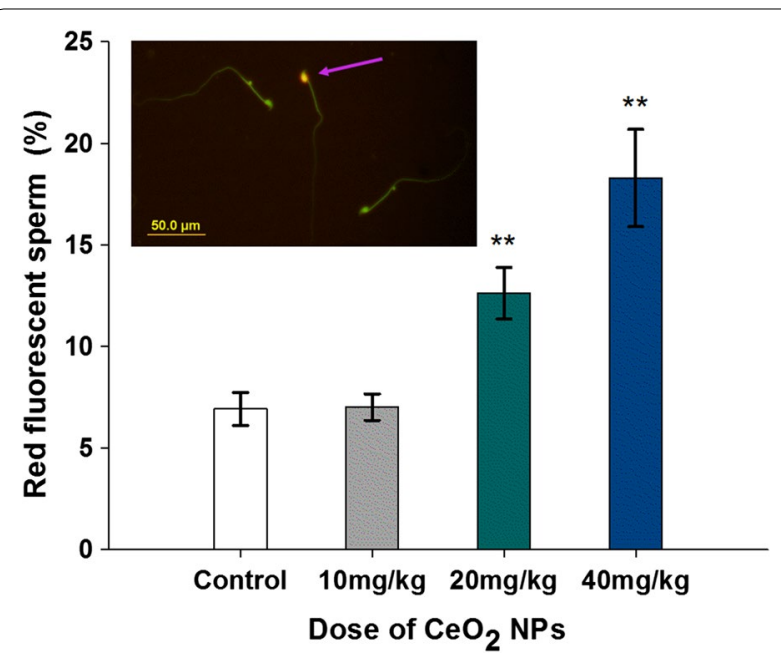

Fig. 5 AO staining result for DNA integrity. The green and red fluorescence indicate the sperm with normal double-stranded DNA and the abnormally denatured DNA, respectively. Arrow shows the sperm head appeared with red fluorescent. Column diagram indicates percentage of red fluorescent labeled sperm in mice exposed to various doses $\mathrm{CeO}_{2} \mathrm{NPs}$. Values are mean $\pm \mathrm{SD}, n=12$. Significance of difference: $\mathrm{CeO}_{2} \mathrm{NPs}$ group compared with control, ${ }^{*} p<0.05,{ }^{* *} p<0.01$

control group, mRNA expression levels of $S f-1$ gene were significantly down-regulated by 0.58 and 0.69 -fold in $\mathrm{CeO}_{2} \mathrm{NPs}$ exposed mice at 20 and $40 \mathrm{mg} / \mathrm{kg}$, respectively. Similar effects of $\mathrm{CeO}_{2}$ NPs on SF-1 protein expression were also observed. Therefore, $\mathrm{CeO}_{2} \mathrm{NPs}$ exposure down-regulated the expression levels of transcription factor SF-1 in mice testis.

\section{Discussion}

Successful reproduction may not be possible in the absence of integrity in male gamete, and impairment of sperm functions can lead to abnormal offsprings [29]. Among the methods in assessment of toxic effects on spermatogenesis, enumeration of testicular sperm head has been widely used as a simple, reproducible, and quantifiable one [30]. Daily sperm production (DSP) is also a common method in detection of testicular toxicity [31]. In the present study, both the methods were used and the results showed that DSP decreased significantly in the 20 and $40 \mathrm{mg} / \mathrm{kg} \mathrm{CeO}{ }_{2}$ NPs group, but not in the $10 \mathrm{mg} / \mathrm{kg}$ group, indicating a high dose effect of $\mathrm{CeO}_{2}$ NPs on the spermatogenesis process. While the increased element $\mathrm{Ce}$ content of testis in nano cerium oxide treatment animals reveal the cerium oxide nanoparticles enter into the testicle and accumulated. The experiment results indicated the toxicity of spermatogenesis induced by high dose $\mathrm{CeO}_{2}$ NPs be correspondence to the increased element $\mathrm{Ce}$ in testicle.
As one of the major determinants of male fertility, the sperm motility reflects its ability of penetration and thus of male reproduction [32]. El-Sabeawy et al. reported that exposure to some toxicants may decrease testicular sperm numbers and sperm motility, and depress acrosome reactions [33]. In the present study, sperm motility was significantly decreased with increasing $\mathrm{CeO}_{2} \mathrm{NPs}$ dose. In addition to parameters such as sperm number, concentration, motility and morphology, another important key marker for sperm quality is chromatin integrity which directly affects reproduction procedure such as fertilization, embryo development, and pregnancy outcome [34]. In this study, AO staining test revealed that the percentage of sperm with single stranded DNA increased significantly in 20 and $40 \mathrm{mg} / \mathrm{kg} \mathrm{CeO} \mathrm{CPS}_{2}$ groups, indicating an impairment of the DNA integrity. The reduction in sperm motility induced by $\mathrm{CeO}_{2} \mathrm{NPs}$ may be due to its damage to sperm cells in epididymis and/or in testicular, since histopathological examination revealed that $\mathrm{CeO}_{2}$ NPs induced a degeneration of spermatids in testicular tissue.

The microscopic examination of testis tissue sections confirmed that $\mathrm{CeO}_{2}$ NPs exposure induced degenerative changes in 20 and $40 \mathrm{mg} / \mathrm{kg}$ groups, such as atrophy/ necrosis of seminiferous tubules and apoptosis in interstitial tissue. Earlier studies reported that some enzymes played important roles in the functional status of specific cell type in testis during germ cell maturation $[35,36]$. Among the testicular enzymes, SDH is relevant to germ cell maturation [37], $\gamma$-GT parallels the maturation and replication of Sertoli cells and, ACP's activity reveals the Sertoli cell function [38]. In spermatogonial cells such as primary/secondary spermatocytes, spermatids and spermatozoon bundles, the advent of ACP may provide phosphate to meet high energy requirements [39]. Activities of $\gamma$-GT, ACP and SDH were decreased upon $\mathrm{CeO}_{2}$ NPs exposure. Besides, G6PDH in Leydig cells were also changed in mice given oral 20 and $40 \mathrm{mg} / \mathrm{kg}$, which would impair testosterone production.

Previous investigations suggested that pathological changes in testes induced by toxic chemicals could alter imbalance in production of sex hormones [40]. Testosterone is known to be indispensable for spermatogenesis and its concentration in the seminiferous tubules is generally $10-100$ times higher than that in blood [41, 42]. Through androgen receptor, testosterone functions on spermatogenesis by acting on Sertoli cells to provide nutritional and morphogenetic support for germ cells $[43,44]$. When entering into the epididymis through efferent ducts, testosterone helps sperm in obtaining progressive motility and fertilization capabilities during maturation [45]. In this study, 20 and $40 \mathrm{mg} / \mathrm{kg} \mathrm{CeO}$ NPs significantly decreased testosterone concentrations 

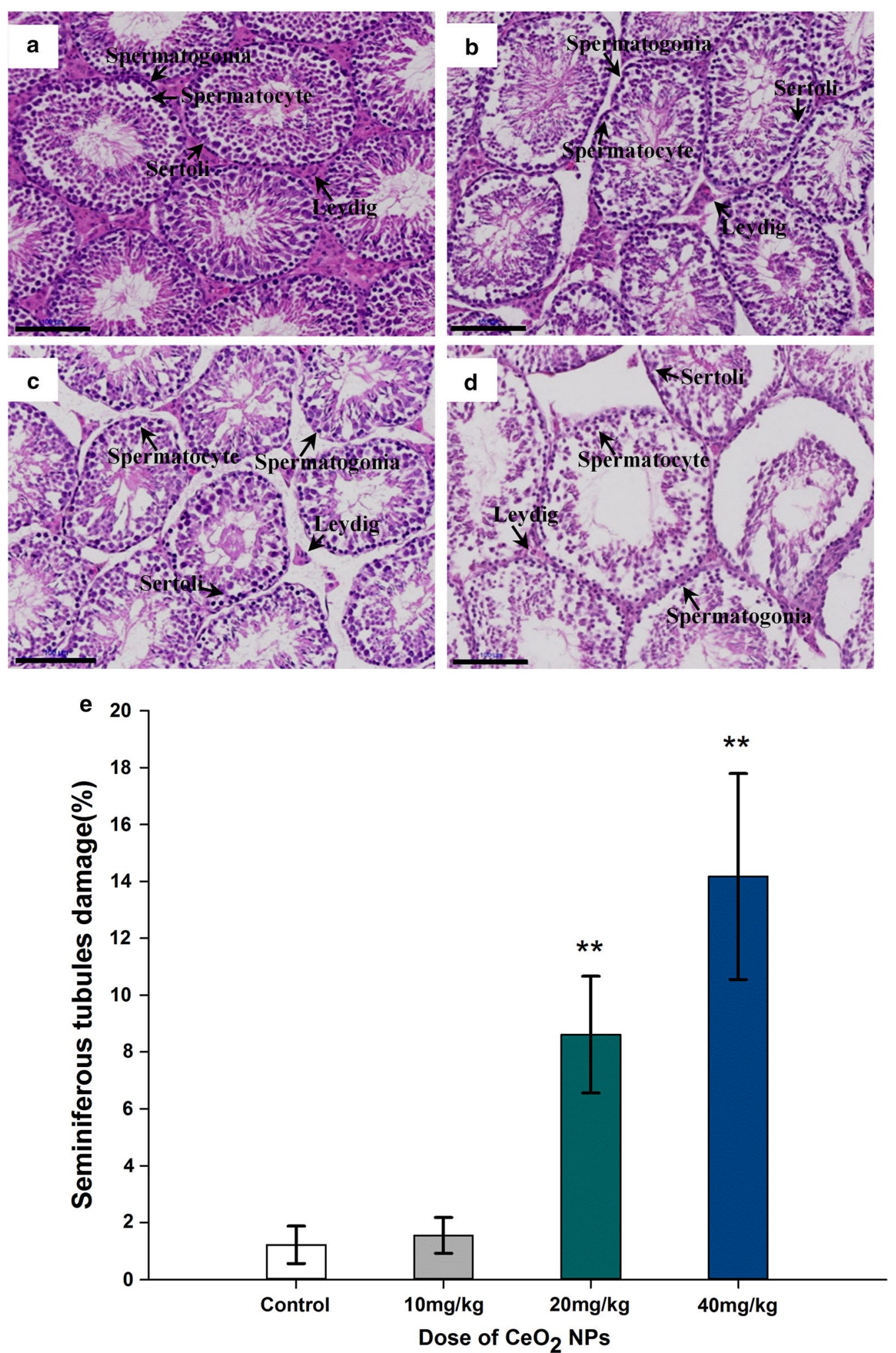

Fig. 6 Histopathological changes in the testis tissues. a-d Photomicrograph of transverse section of H\&E staining of mice in control, $\mathrm{CeO}_{2} \mathrm{NPS}$ groups (10, 20 and $40 \mathrm{mg} / \mathrm{kg}$ ), Bar length $=100$ microns. e The percentage of degenerative seminiferous tubules in testicular cross sections. Values are mean $\pm \mathrm{SD}, n=6$. Significance of difference: $\mathrm{CeO}_{2} \mathrm{NPs}$ group compared with control, ${ }^{*} p<0.05,{ }^{*} p<0.01$ 

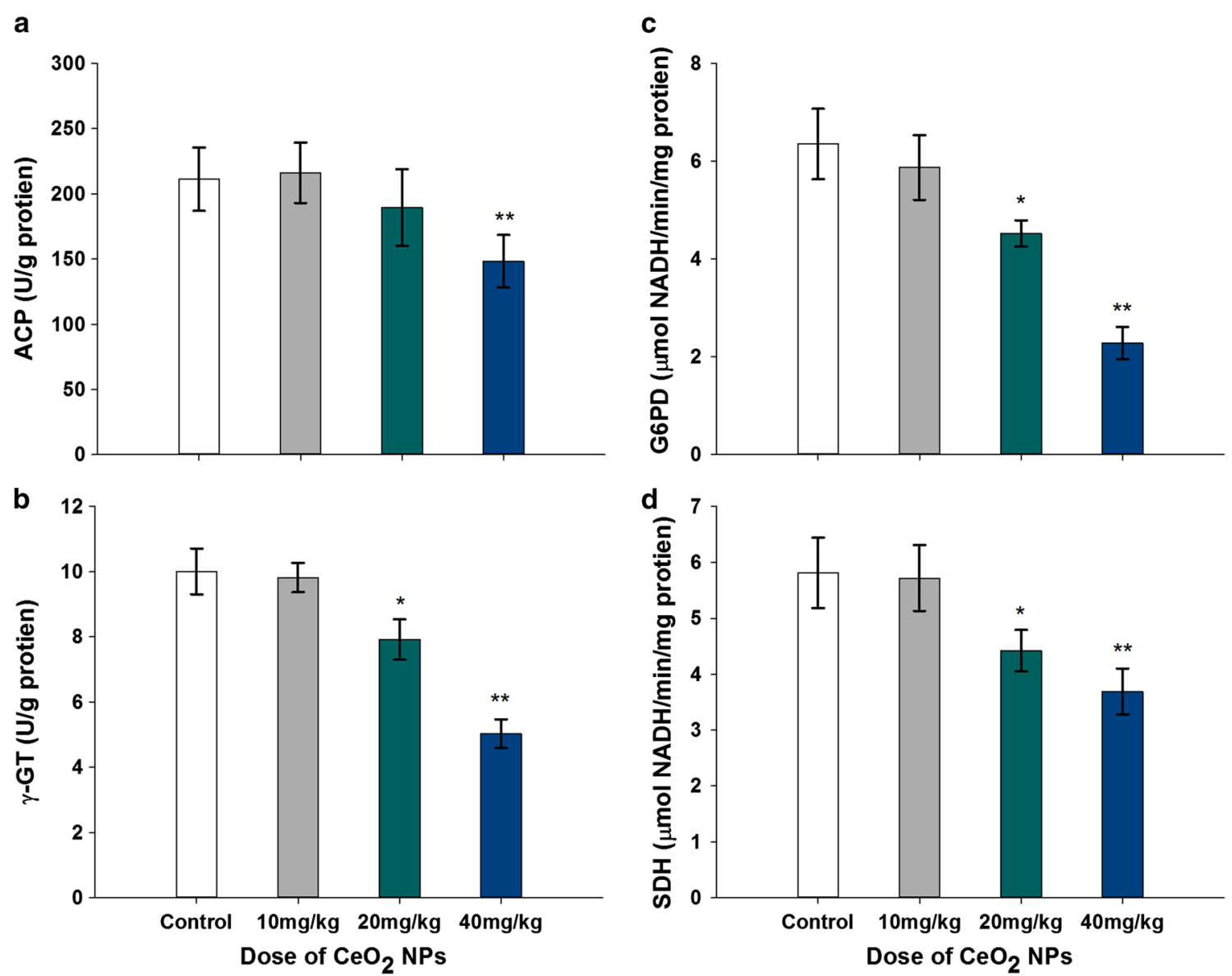

Fig. 7 Changed activities' levels of testicular marker enzymes, ACP (a), y-GT (b), G6PD (c) and SDH (d) in mice following the addition of various

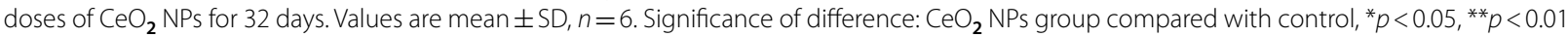

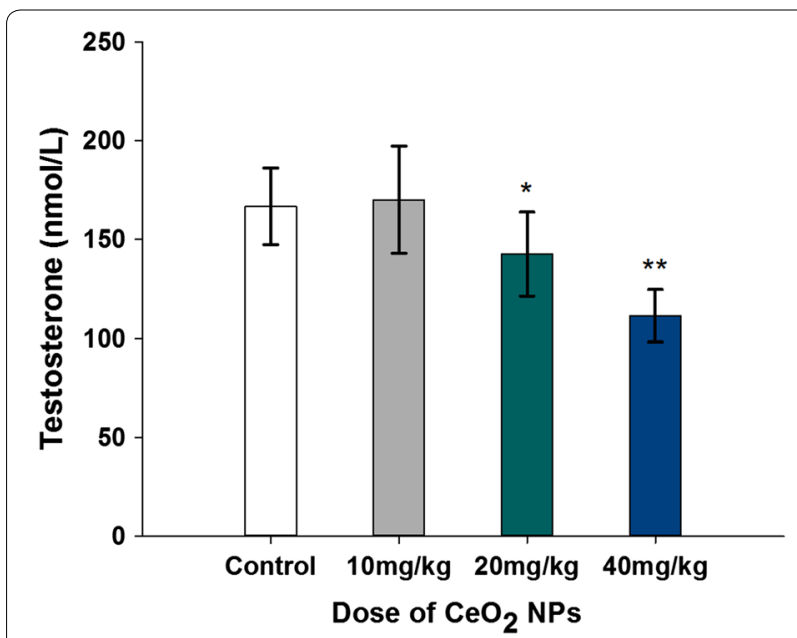

Fig. 8 Reduced levels of plasma testosterone in mice following the addition of various doses of $\mathrm{CeO}_{2} \mathrm{NPs}$ for 32 days. Values are mean $\pm \mathrm{SD}, n=12$. Significance of difference: $\mathrm{CeO}_{2} \mathrm{NPs}$ group compared with control, ${ }^{*} p<0.05,{ }^{* *} p<0.01$ in plasma, indicating the potential that lack of testosterone may lead to disorders in spermatogenesis and maturation and therefore infertility [46].

Testosterone is mainly produced in the Leydig cells in testis by a series of enzymatic reactions. As the first step, the mitochondrial cytochrome P450scc enzyme system transforms cholesterol to pregnenolone $[47,48]$. Then, other testosterone synthesis enzymes $(3 \beta-\mathrm{HSD}$, P450c17, 17 $\beta$-HSD) convert the pregnenolone to testosterone [49]. For testosterone synthesis, transferring of cholesterol to mitochondria requires steroidogenic acute regulatory protein (StAR) which is considered to be the rate-limiting step in steroid biosynthesis [50]. At the gene expression level, the function of Leydig cells is largely dependent upon the genes coding StAR protein, cytochrome P450cc and P450c17, HSD $3 \beta$ and HSD $17 \beta$. In the present study, the genes coding these enzymes were significantly down-regulated, which may result in reduced synthesis of male hormone and impaired maturation of sperm. 

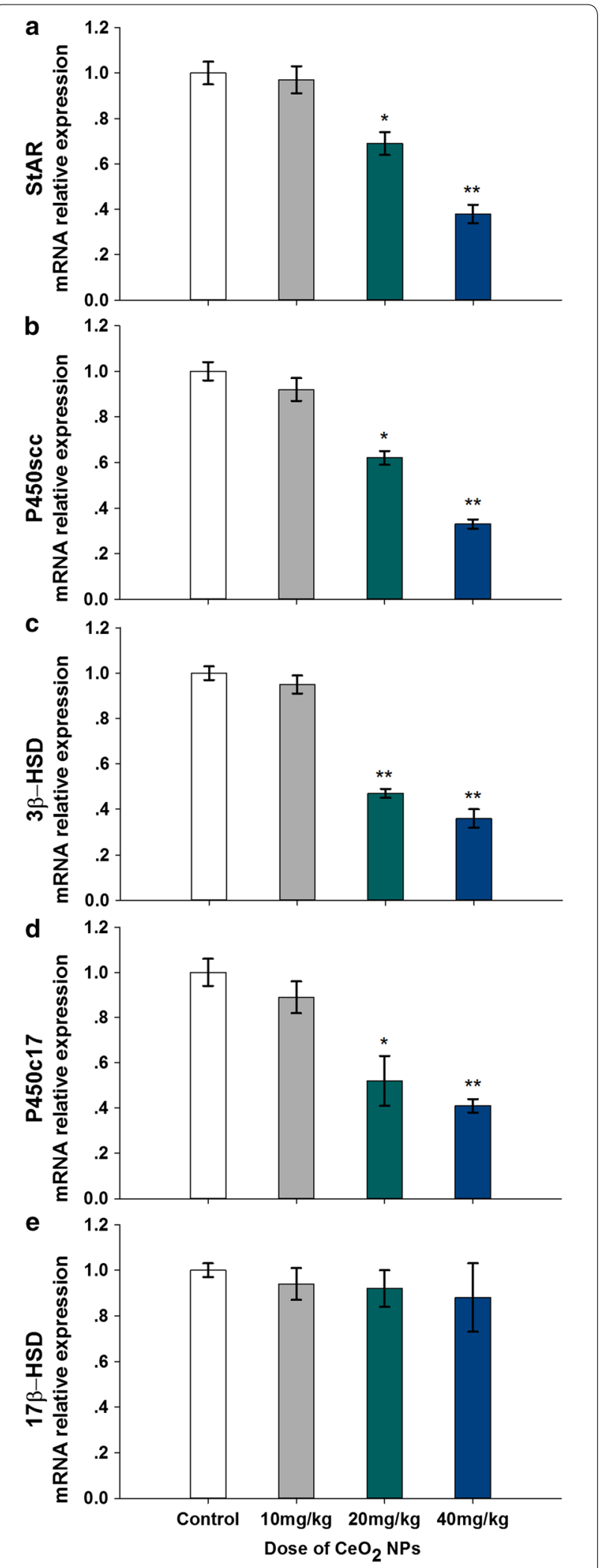

Fig. 9 Changed expression levels of testosterone synthetic genes, $\operatorname{StAR}(\mathbf{a}), \operatorname{P450SCC}(\mathbf{b}), 3 \beta-H S D(\mathbf{c}), P 450 \mathrm{c} 17$ (d) and 17ß-HSD (e) in testes of mice following the addition of various doses of $\mathrm{CeO}_{2} \mathrm{NPs}$ for 32 days. Values are mean $\pm S D, n=6$. Significance of difference: $\mathrm{CeO}_{2}$ NPs group compared with control, ${ }^{*} p<0.05,{ }^{* *} p<0.01$

The genes expression encoding these enzymes is tightly under the control of a battery of transcription factors in the testes [51]. The expression of key protein StAR that plays an essential role in testosterone synthesis was reported to be regulated by steroidogenic factor-1 (SF-1, NR5A1, Ad4BP) [52], which is a nuclear receptor regulatory gene involved in steroidogenesis, adrenal/gonadal development and the reproductive axis [53]. The investigation into human infertility cases from Bashamboo and co-workers found that the men who harbored NR5A1 changes had lower levels of testosterone and more fateful infertility such as azoospermia and oligozoospermia [54]. SF-1 has been reported to increase expression of the machinery of steroid biosynthesis by binding to its response element site in the promoter regions of the genes encoding for StAR, Hydroxysteroid dehydrogenases $(3 \beta-H S D, 17 \beta-H S D)$ and cytochrome P450 steroid hydroxylase (CYP) enzymes including P450scc and P450c17 [55-57]. In testosterone biosynthesis, P450c17 converts pregnenolone to dehydroepiandrostenedione (DHEA) in the sex steroid pathways. SF-1 activates transcription of the P450c17 gene whose promoter containing three functional SF-1 sites through multiple cis-elements [58, 59]. In SF-1 knockout mice, hypoplastic testes were observed with the obstacle of spermatogonia development into mature sperm, together with markedly decreased expression of P450scc and StAR, two essential components of testosterone biosynthesis in leydig cell [60-62]. In this study, the reduced gene expression levels of testosterone synthesis gene

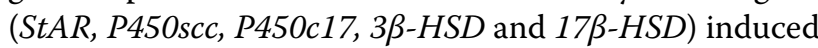
by $\mathrm{CeO}_{2} \mathrm{NPs}$ exposure was correlated with down-regulated mRNA and protein levels of SF-1 gene expression. This correlation prompts a possibility of SF- 1 as a mediator of reduced testosterone synthesis by $\mathrm{CeO}_{2} \mathrm{NPs}$ treatment, but further tests are needed.

It is worth noting that the results of $\mathrm{CeO}_{2} \mathrm{NPs}$ treatment will exhibit different effects to the sperm quality in male animals due to dose, nanoparticle size, animals' kinds, administration methods such as peroral (PO), intravenous (IV), and intraperitoneal (IP). The data changes in the present study agree with a report in mice administrated with $\mathrm{CeO}_{2} \mathrm{NPs}$ via intraperitoneal (IP) route by $100-300 \mu \mathrm{g} / \mathrm{kg} \mathrm{BW}$ thrice/week for 35 days [63]. 


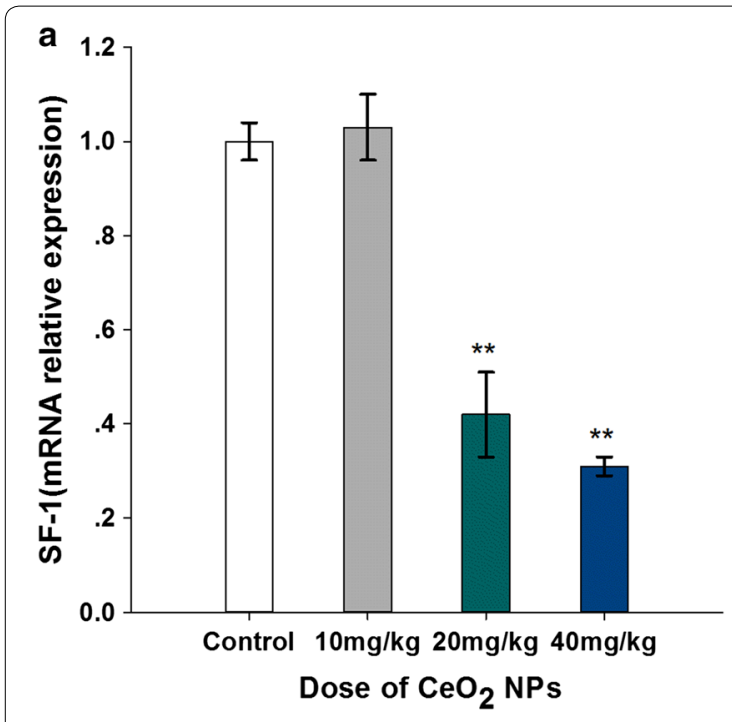

${ }^{\text {b }} 55 \mathrm{kDa}$

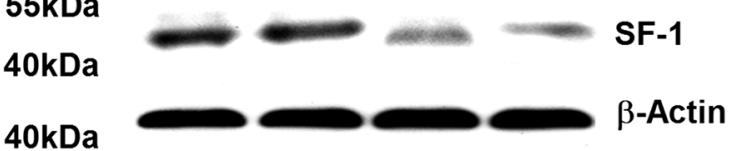

Fig. 10 Changed mRNA (a) and protein (b) expression levels of steroidogenic factor- 1 in testes of mice following the addition of various doses of $\mathrm{CeO}_{2} \mathrm{NPs}$ for 32 days. Values are mean $\pm \mathrm{SD}, n=6$. Significance of difference: $\mathrm{CeO}_{2} \mathrm{NPs}$ group compared with control, ${ }^{* *} p<0.01$

Although another literature reported that the $\mathrm{CeO}_{2} \mathrm{NPs}$ administration $(30 \mathrm{mg} / \mathrm{kg}$, IP) for fourteen days can ameliorate sperm and testicular damage induced by diabetes in rats, it alone still distinctly reduced the leydig cell density, sertoli cell density, inner and outer diameter of seminiferous tubule in testis [64]. Therefore, the results obtained in the present study exhibited the peroral (PO) effect of $\mathrm{CeO}_{2}$ NPs exposure on male mice reproductive toxicity for consecutive 32 days. Meanwhile, the results from this study present the public with precaution for reasonable application of cerium oxide nanomaterial.

\section{Conclusion}

In this study, long-term, oral administration of $\mathrm{CeO}_{2}$ NPs at doses over $20 \mathrm{mg} / \mathrm{kg}$ could impair male reproductive functions by decreasing sperm count and motility, destructing DNA integrity and disturbing testosterone synthesis with down-regulation of transcription regulation factor SF-1. This work hints that the utilization of $\mathrm{CeO}_{2}$ NPs needs to be carefully evaluated about their potential reproductive toxicity on the human health.

\section{Additional file}

Additional file 1: Fig. S1. Original image of SF-1 Western blots.

\section{Authors' contributions}

FQ_corresponding author, proposed study design, prepared manuscript, analyzed data, and do the whole experiments with TS and JL. JZ analyzed marker enzymes and sperm DNA. JQ and TS contributed to Ce content test, characterization and ultra structural analysis of nanoparticle. GZ analyzed data of molecular assays. JT-co-corresponding author, modified manuscript, proposed study design. All authors reviewed and interpreted the data. All authors read and approved the final manuscript.

\section{Author details}

${ }^{1}$ School of Chemistry, Biology and Material Engineering, Suzhou University of Science and Technology, Suzhou 215009, China. ${ }^{2}$ School of Public Health, Medical College of Soochow University, Suzhou 215123, China. ${ }^{3}$ School of Radiation Medicine and Protection, Medical College of Soochow University, Suzhou 215123, China.

\section{Acknowledgements}

Thanks the support from the NSFC, the SSTD project, the China Postdoctoral Science Foundation, PAPD of Jiangsu Higher Education Institutions and the Jiangsu Key Lab of senile disease prevention and translational medicine.

\section{Competing interests}

The authors declare that they have no competing interests.

\section{Availability of data}

All data generated or analyzed during this study are included in this published article.

\section{Consent for publication}

Not applicable.

\section{Ethics approval and consent to participate}

The animal experiments in this study were conducted according to the guidelines and with ethical standards of the Animal Care \& Welfare Committee of Soochow University, and all the procedures were reviewed and approved by the Committee (Approval Number 201701A326) on 20 February 2017.

\section{Funding}

The design,material and analysis in this work was funded by the National Natural Science Foundation of China (81773463) and the Suzhou Science and Technology Development project (SNG2017055). The collection and detection was funded by the China Postdoctoral Science Foundation (2016M601883). The interpretation of data was funded by the Jiangsu Key Lab of senile disease prevention and translational medicine, and the Priority Academic Program Development of Jiangsu Higher Education Institutions (PAPD).

\section{Publisher's Note}

Springer Nature remains neutral with regard to jurisdictional claims in published maps and institutional affiliations.

Received: 25 September 2018 Accepted: 9 March 2019

Published online: 21 March 2019

\section{References}

1. Vance ME, Kuiken T, Vejerano EP, McGinnis SP, Hochella MF, Rejeski D, Hull MS. Nanotechnology in the real world: redeveloping the nanomaterial consumer products inventory. Beilstein J Nanotech. 2015;6:1769-80.

2. Chen R, Riviere JE. Biological and environmental surface interactions of nanomaterials: characterization, modeling, and prediction. Wiley Interdiscip Rev Nanomed Nanobiotechnol. 2017;9:1. https://doi.org/10.1002/ wnan.1440. 
3. Greish K, Thiagarajan G, Ghandehari H. In vivo methods of nanotoxicology. Methods Mol Biol. 2012;9:26235-53.

4. Arora S, Rajwade JM, Paknikar KM. Nanotoxicology and in vitro studies: the need of the hour. Toxicol Appl Pharmacol. 2012;258:151-65.

5. Sarkar A, Fatima I, Jamal QMS, Sayeed U, Khan MKA, Akhtar S, Kamal MA, Farooqui A, Siddiqui MH. Nanoparticles as a carrier system for drug delivery across blood brain barrier. Curr Drug Metab. 2017;18:129-37.

6. Pietroiusti A, Campagnolo L, Fadeel B. Interactions of engineered nano -particles with organs protected by internal biological barriers. Small. 2013;9:1557-72

7. Joydeep D, Choi YJ, Yasuda H, Han JW, Park C, Song H, Bae H, Kim JH. Efficient delivery of C/EBP beta gene into human mesenchymal stem cells via polyethylenimine-coated gold nanoparticles enhances adipogenic differentiation. Sci Rep. 2016;6:33784.

8. Soni D, Gandhi D, Tarale P, Bafana A, Pandey RA, Sivanesan S. Oxidative stress and genotoxicity of zinc oxide nanoparticles to pseudomonas species, human promyelocytic leukemic (HL-60), and blood Cells. Biol Trace Elem Res. 2017;178:1-10.

9. Kong L, Gao X, Zhu J, Cheng K, Tang M. Mechanisms involved in reproductive toxicity caused by nickel nanoparticle in female rats. Environ Toxicol. 2016;31:1674-83.

10. Ong C, Lee QY, Cai Y, Liu X, Ding J, Yung LY, Bay BH, Baeg GH. Silver nanoparticles disrupt germline stem cell maintenance in the Drosophila testis. Sci Rep. 2016;6:20632

11. Kobayashi E, Watabe Y, Yamamoto T. Yoichi Yamada: Cerium oxide and hydrogen co-doped indium oxide films for high-efficiency silicon heterojunction solar cells. Sol Energy Mater Sol Cells. 2016;149:75-80.

12. Wang Z, Deng Y, Shen G, Akram S, Han N, Chen Y, Wang Q. Catalytic degradation of benzene over nanocatalysts containing cerium and manganese. Chemistry Open. 2016;5:495-504.

13. Zamiri R, Ahangar HA, Kaushal A, Zakaria A, Zamiri G, Tobaldi D, Ferreira JMF. Dielectrical properties of $\mathrm{CeO}_{2}$ nanoparticles at different temperatures. PLoS ONE. 2015;10:e0122989.

14. Aalapati S, Ganapathy S, Manapuram S, Anumolu G, Prakya BM. Toxicity and bio-accumulation of inhaled cerium oxide nanoparticles in CD1 mice. Nanotoxicology. 2014;8:786-98.

15. Hirst SM, Karakoti A, Singh S, Self W, Tyler R, Seal S, Reilly CM. Bio-distribution and in vivo antioxidant effects of cerium oxide nanoparticles in mice. Environ Toxicol. 2013;28:107-18.

16. Mortazavi Milani Z, Charbgoo F, Darroudi M. Impact of physicochemical properties of cerium oxide nanoparticles on their toxicity effects. Ceram Int. 2017:43:14572-81.

17. Preaubert L, Courbiere B, Achard V, Tassistro V, Greco F, Orsiere T, Bottero $J Y$, Rose J, Auffan M, Perrin J. Cerium dioxide nanoparticles affect in vitro fertilization in mice. Nanotoxicology. 2016;10:111-7.

18. Perrin J, Tassistro V, Auffan M, Liu W, Botta A, Sari-Minodier I, Bottero J, Orsière T, Rose J, Courbiere B. Cerium dioxide nanoparticles induce DNA damage in human spermatozoa. In: Abstracts of the 30th Annual Meeting of the European Society of Human Reproduction and Embryology, Germany. Oxford: Human. Reproduction. 2014, 29 suppl 1:18-i9.

19. Falchi L, Bogliolo L, Galleri G, Ariu F, Zedda MT, Pinna A, Malfatti L, Innocenzi P, Ledda S. Cerium dioxide nanoparticles did not alter the functional and morphologic characteristics of ram sperm during short-term exposure. Theriogenology. 2015;85:1274-81.

20. Geraets L, Oomen AG, Schroeter JD, Coleman VA, Cassee FR. Tissue distribution of inhaled micro- and nano-sized cerium oxide particles in rats: results from a 28-day exposure study. Toxicol Sci. 2012;127:463-73.

21. Greco F, Courbière B, Rose J, Orsière T, Sari-Minodier I, Bottero JY, Auffan $M$, Perrin J. Toxicity of nanoparticles on reproduction. Gynecol Obstet Fertil. 2015;43:49-55.

22. Nia Y, Millour S, Noel L, Krystek P, de Jong W, Guérin T. Determination of Ti from $\mathrm{TiO} 2$ nanoparticles in biological materials by different ICP-MS instruments: method validation and applications. J Nanomed Nanotechnol. 2015:6:1-8.

23. Thakur M, Gupta H, Singh D, Mohanty IR, Maheswari U, Vanage G, Joshi DS. Histopathological and ultra structural effects of nanoparticles on rat testis following 90 days (Chronic study) of repeated oral administration. J Nanobiotechnol. 2014;12:42.

24. Yoshida S, Hiyoshi K, Oshio S, Takano H, Takeda K, Ichinose T. Effects of fetal exposure to carbon nanoparticles on reproductive function in male offspring. Fertil Steril. 2010;93:1695-9.
25. Joyce KL, Porcelli J, Cooke PS. Neonatal goitrogen treatment increases adult testis size and sperm production in the mouse. J Androl. 1993:14:448-55.

26. Blazak WF, Treinen KA, Juniewicz PE. Application of testicular sperm head counts in the assessment of male reproductive toxicity. Male Reproduct Toxicol. 1993;3:86-94.

27. Duale N, Steffensen IL, Andersen J, Brevik A, Brunborg G, Lindeman B. Impaired sperm chromatin integrity in obese mice. Andrology. 2014:2:234-43.

28. Qin FJ, Zhang J, Zan L, Guo W, Wang J, Chen L, Cao Y, Shen O, Tong $J$. Inhibitory effect of melatonin on testosterone synthesis is mediated via GATA-4/SF-1 transcription factors. Reprod BioMed Online. 2015;11:638-46.

29. Gallo A, Boni R, Buttino I, Tosti E. Spermiotoxicity of nickel nanoparticles in the marine invertebrate Ciona intestinalis (ascidians). Nanotoxicology. 2016;10:1096-104.

30. Zenick H, Clegg ED. Assessment of male reproductive toxicity: a risk assessment approach. In: Hayes (Ed.) Principles and methods of toxicology, 2nd ed. New York: Raven Press; 1989. p. 275-309.

31. Garcia PV, Arrotéia KF, Joazeiro PP, de Mesquita SFP, de Kempinas GW, Pereira LA. Orchidopexy restores morphometric-stereologic changes in the caput epididymis and daily sperm production in cryptorchidic mice, although sperm transit time and fertility parameters remain impaired. Fertil Steril. 2011;96:739-44.

32. Au DW, Chiang MW, Tang JY, Yuen BB, Wang YL, Wu RS. Impairment of sea urchin sperm quality by UV-b radiation: predicting fertilization success from sperm motility. Mar Pollut Bull. 2002;44:583-9.

33. El-Sabeawy F, Wang S, Overstreet J, Miller M, Lasley B, Enan E. Treatment of rats during pubertal development with 2,3,7,8-tetrachlorodibenzo-pdioxin alters both signaling kinase activities and epidermal growth factor receptor binding in the testis and the motility and acrosomal reaction of sperm. Toxicol Appl Pharmacol. 1998;150:427-42.

34. Oleszczuk K, Giwercman A, Bungum M. Serm chromatin structure assay in prediction of in vitro fertilization outcome. Andrology. 2016;4:290-6.

35. Adedara IA, Awogbindin IO, Adesina AA, Oyebiyi OO, Lawal TA, Farombi EO. Municipal landfill leachate-induced testicular oxidative damage is associated with biometal accumulation and endocrine disruption in rats. Arch Environ Contam Toxicol. 2015;68:74-82.

36. Srivastava S, Seth PK, Srivastava SP. Effect of styrene administration on rat testis. Arch Toxicol. 1989;63:43-6.

37. Pant N, Prasad AK, Srivastava SC, Shankar R, Srivastava SP. Effect of oral administration of carbofuran on male reproductive system of rat. Hum Exp Toxicol. 1995;14:889-94.

38. Aly HA, Lightfoot DA, El-Shemy HA, Lightfoot DA, El-Shemy HA. Bacterial lipopolysaccharide-induced oxidative stress in adult rat Sertoli cells in vitro. Toxicol In Vitro. 2010:24:1266-72.

39. Peruquetti RL, Taboga SR, Azeredo-Oliveira MT. Expression of acid phosphatase in the seminiferous epithelium of vertebrates. Genet Mol Res. 2010:9:620-8.

40. Reshma AM, Sreenivasula RP. Recovery of lead-induced suppressed reproduction in male rats by testosterone. Andrologia. 2015;47:560-7.

41. Toocheck C, Clister T, Shupe J, Crum C, Ravindranathan P, Lee TK, Ahn JM, Raj GV, Sukhwani M, Orwig KE, Walker WH. Mouse spermatogenesis requires classical and nonclassical testosterone signaling. Biol Reprod. 2016;94:11.

42. Turner TT, Jones CE, Howards SS, Ewing LL, Zegeye B, Gunsalus GL. On the androgen microenvironment of maturing spermatozoa. Endocrinology. 1984;15:1925-32

43. Griswold MD. The central role of Sertoli cells in spermatogenesis. Semin Cell Dev Biol. 1998:9:411-6.

44. Kaur G, Thompson LA, Dufour JM. Sertoli cells-immunological sentinels of spermatogenesis. Semin Cell Dev Biol. 2014;30:36-44.

45. Hamzeh M, Robaire B. Effect of testosterone on epithelial cell proliferation in the regressed rat epididymis. J Androl. 2009;30:200-12.

46. Ohlander SJ, Lindgren MC, Lipshultz LI. Testosterone and male infertility. Urol Clin North Am. 2016:43:195-202.

47. Davydov R, Strushkevich N, Smil D, Yantsevich A, Gilep A, Usanov S, Hoffman BM. Evidence that compound I is the active species in both the hydroxylase and lyase steps by which P450scc converts cholesterol to pregnenolone: EPR/ENDOR/cryoreduction/annealing studies. Biochemistry. 2015;54:7089-97. 
48. Yoshimoto FK, Jung IJ, Goyal S, Gonzalez E, Guengerich FP. Isotopelabeling studies support the electrophilic compound I iron active species, $\mathrm{FeO}(3+)$, for the carbon-carbon bond cleavage reaction of the cholesterol side-chain cleavage enzyme, cytochromeP450 11A1. J Am Chem Soc. 2016;138:12124-41.

49. Miller WL. Steroid hormone synthesis in mitochondria. Mol Cell Endocrinol. 2013;379:62-73.

50. Mesmin B, Pipalia NH, Lund FW, Ramlall TF, Sokolov A, Eliezer D, Maxfield FR. STARD4 abundance regulates sterol transport and sensing. Mol Biol Cell. 2011;22:4004-15.

51. Lavoie HA, King SR. Transcriptional regulation of steroidogenic genes: STARD1, CYP11A1 and HSD3B. Exp Biol Med. 2009;234:880-907.

52. Hoivik EA, Lewis AE, Aumo L, Bakke M. Molecular aspects of steroidogenic factor 1 (SF-1). Mol Cell Endocrinol. 2010;315:27-39.

53. Köhler B, Achermann JC. Update-steroidogenic factor 1 (SF-1, NR5A1) Minerva Endocrinol. 2010;35:73-86.

54. Bashamboo A, Ferraz-de-Souza B, Lourenço D, Lin L, Sebire NJ, Montjean D, Bignon-Topalovic J, Mandelbaum J, Siffroi JP, Christin-Maitre S, Radhakrishna U, Rouba H, Ravel C, Seeler J, Achermann JC, McElreavey K. Human male infertility associated with mutations in NR5A1 encoding steroidogenic factor 1. Am J Hum Genet. 2010;87:505-12.

55. Chai Z, Brereton P, Suzuki T, Sasano H, Obeyesekere V, Escher G, Saffery R, Fuller P, Enriquez C, Krozowski Z. 17 beta-hydroxysteroid dehydrogenase type XI localizes to human steroidogenic cells. Endocrinology. 2003;144:2084-91.

56. Leers-Sucheta S, Morohashi K, Mason Jl, Melner MH. Synergistic activation of the human type II 3beta-hydroxysteroid dehydrogenase/delta5delta4 isomerase promoter by the transcription factor steroidogenic factor-1/adrenal 4-binding protein and phorbol ester. J Biol Chem. 1997;272:7960-7.

57. Mizutani T, Ishikane S, Kawabe S, Umezawa A, Miyamoto K. Transcriptional regulation of genes related to progesterone production. Endocr J. 2015;62:757-63.

58. Hanley NA, Rainey WE, Wilson DI, Ball SG, Parker KL. Expression profiles of SF-1, DAX1, and CYP17 in the human fetal adrenal gland: potential interactions in gene regulation. Mol Endocrinol. 2001;15:57-68.

59. Bakke M, Zhao L, Hanley NA, Parker KL. SF-1: a critical mediator of steroidogenesis. Mol Cell Endocrinol. 2001;171:5-7.

60. Jeyasuria P, Ikeda Y, Jamin SP, Zhao L, de Rooij DG, Themmen AP, Behringer RR, Parker KL. Cell-specific knockout of steroidogenic factor 1 reveals its essential roles in gonadal function. Mol Endocrinol. 2004;18:1610-9.

61. Zhao L, Bakke M, Hanley NA, Majdic G, Stallings NR, Jeyasuria P, Parker KL. Tissue-specific knockouts of steroidogenic factor 1. Mol Cell Endocrinol. 2004;215:89-94.

62. Hatano M, Migita T, Ohishi T, Shima Y, Ogawa Y, Morohashi Kl, Hasegawa Y, Shibasaki F. SF-1 deficiency causes lipid accumulation in Leydig cells via suppression of STAR and CYP11A1. Endocrine. 2016;54:484-96.

63. Adebayo OA, Akinloye O, Adaramoye OA. Cerium oxide nanoparticle elicits oxidative stress, endocrine imbalance and lowers sperm characteristics in testes of balb/c mice. Andrologia. 2018;50:1. https://doi.org/10.1111/ and. 12920.

64. Artimani T, Amiri I, Soleimani Asl S, Saidijam M, Hasanvand D, Afshar S. Amelioration of diabetes-induced testicular and sperm damage in rats by cerium oxide nanoparticle treatment. Andrologia. 2018;50:e13089. https ://doi.org/10.1111/and.13089.
Ready to submit your research? Choose BMC and benefit from:

- fast, convenient online submission

- thorough peer review by experienced researchers in your field

- rapid publication on acceptance

- support for research data, including large and complex data types

- gold Open Access which fosters wider collaboration and increased citations

- maximum visibility for your research: over 100M website views per year

At BMC, research is always in progress.

Learn more biomedcentral.com/submissions 